\title{
Beyond Risk Management, Toward Ethics: Institutional und Evolutionary Perspectives
}

\section{Introduction}

The management of risk - on a societal level or related to organizational measures 5 in businesses - is important and it is clearly related to moral concerns in life. The 6 risky speculations in the financial sector in the past years have demonstrated this 7 in the same manner as the nuclear catastrophe in Fukushima. Corruption cases, 8 fraud issues, irresponsible mismanagement, risky products and other examples 9 clearly show the importance of compliance measures in firms to manage risk on 10 an organizational level. The main logic is "avoiding harm" to others - and who 11 would deny that this is not ethically relevant. Of course it is.

In this paper, however, I argue that considering risk in business ethics is necessary 13 but not sufficient for addressing these moral concerns since ethics in general is not 14 merely about avoiding harm, but also about "a good life", and because business 15 ethics in particular is not merely about avoiding "bad practices", such as corruption 16 and fraud, but also about reflections on "good business practices". Hence, risk 17 management is neither identical with business ethics nor do the notion and concepts 18 of risk management reflect the main challenges in the field of business ethics. $\quad 19$

In the following sections I will first elaborate on some general normative 20 perspectives in business ethics and then, based on these reflections, suggest two 21 complementary institutional measures for firms. I will argue that compliance 22 approaches need to be supplemented with by a so-called integrity approaches that 23 not only bring the individual as (moral) actor back into play but also characterize 24 more reflective institutional measures within the organization to foster corporate 25 social responsibility.

T. Beschorner $(\bowtie)$ 
In the past decades we can observe the negative consequences of a decoupling 28 process between the private and public domains. The lack of national regulatory 29 mechanisms has enabled fraud and unethical behavior within businesses. However, 30 this rise in ethical problems seems to have raised interest in some aspects of 31 social responsibility among businesses in modern societies. Since the late 1980s, 32 an increasing number of publications on business ethics and an increasing number 33 of business practices related to certain ethical issues have emerged. $\quad 34$

We suggest interpreting these developments against the backdrop of the re- 35 composition of society. Owing to the breakdown of the public and private dialectics, 36 the tacit contract between firms and society - to maximize your profits, provide the 37 population with work, the consumers with low prices for goods, while the politicians 38 regulate our activities within the political framework - has lost some of its binding 39 capacity. Firms are increasingly the focus of a critical society. Firms are seen as 40 being responsible for their economic actions.

In the academic debate on business ethics we can identify two dominant streams 42 of argumentation. The one can be located within the economic paradigm: 'Neo- 43 classical free-market libertarians believe that we need to rely more - not less - on 44 markets and economic rationality. They argue in favor of self-interested economic 45 actors and highly deregulated markets. Consequently, businesses ought to take 46 ethical issues into account if - and only if - there is a pay-off. The other stream - 47 we can call them the 'radical critics' - argue for the exact opposite: Their critique 48 is aimed at what they believe are the foundations of market economies, such as 49 managers' and bankers' 'greed'. They want companies to engage in ethically sound 50 behavior, and for the state to regulate economic actors strictly.

I argue that both perspectives have serious shortcomings, since they are limited to 52 either, on the one hand, economic circumstances and the assumption that businesses 53 are merely motivated by profits without considering the normative justification of 54 such a motive (free-market scholars), or, on the other, to discussing firms' "dos" 55 and "don'ts" without taking into consideration societal realities. 56

We suggest extending the debate in business ethics by rephrasing it with the 57 following questions: What do businesses actually do to contribute to a "good 58 society"? What do they want to, what can they, and finally, what should they, do 59 in order to better contribute?

The first question refers to concrete practices and empirical facts. "What do they 61 want to do?" concerns the motivation of businesses to get involved in corporate 62 social responsibility (which can be profit seeking or other motivations). "What can 63 they do?" asks about the capabilities that are needed to be a "good corporate citizen" 64 (on an individual as well as on an organizational level). And "what should they do?" 65 reflects the role of businesses in society far beyond the other three elements.

If we apply this typology to the business ethics debate on risk management 67 we can see that it somehow touches on the first three questions, but also that the 68 


\section{Author's Proof}

Beyond Risk Management, Toward Ethics: Institutional und Evolutionary Perspectives

businesses' role of contributing to a good society is somehow less present und much 69 less debated. Here "pure market systems" are either implicitly taken for granted or 70 explicitly justified on a normative basis with a combination of Friedman's (1970) 71 well-known phrase that the social responsibility of a business is to increase its profits 72 and the necessity of political regulations.

Indeed, if it would be possible through national regulations to fully internalize 74 negative external effects into the cost-benefit calculation of businesses, then there 75 would be no need to talk about corporate social responsibility. Firms - the players -76 could then maximize their profits, while questions of social justice could be realized 77 through political regulations, the rules of the game (Homann and Blome-Drees 78 1992; Homann 1993). Unfortunately, this simple idea does not work so well 79 anymore in times of a "world society," where the economy and business interactions 80 and transactions are globalized while the major regulatory measurement - law - is 81 still mainly limited to a locally acting nation state. This is certainly a pity but a fact 82 of modern societies that cannot be overlooked.

This new societal configuration (Beschorner 2004) has led to a different under- 84 standing of businesses and their role not just as economic but also as political actors 85 (Palazzo and Scherer 2006; Scherer et al. 2006). We cannot, whether empirically 86 or normatively simply describe, explain or justify businesses in a given political 87 framework (Beschorner and Vorbohle 2007). Rather we need to extend our analysis 88 to a more complex interplay of different actors (including political actors) that 89 contribute to new forms of normative contexts (purposefully three times plural). $\quad 90$

What is important are the normative roles of businesses in these "enjeux" that 91 are often collected under the heading of "corporate citizenship": The firm is an 92 actor with liberal rights as well as republican duties or responsibilities (Matten and 93 Crane 2005). Businesses are de facto contributors to governance structures; they are 94 quasi-governmental actors. The question is: How can they contribute proactively 95 to a "good society?" I regard this normative premise, this "ideal" of businesses as 96 "good corporate citizen" as widely accepted in the international debate on business 97 ethics.

However, a remaining question beyond this "ought to be" is obviously how to 99 bring this into practice, or, more precisely, how to bring the "ought to be" and the 100 "is" into fruitful interplay?

\section{Institutional and Evolutionary Perspectives}

In approaching an answer to this question, I will discuss two economic approaches 103 to highlight different theoretical perspectives of business ethics. These are, on the 104 one hand, what we call traditional economic perspectives, (neoclassical ideas, but 105 especially approaches in New Institutional Economics) and, on the other hand, 106 an alternative economic approach mainly oriented toward ideas associated with 107 Evolutionary Economics. It will be demonstrated that neither one can serve as a 108 


\section{Author's Proof}

T. Beschorner

Fig. 1 Business ethics from a neoclassical perspective
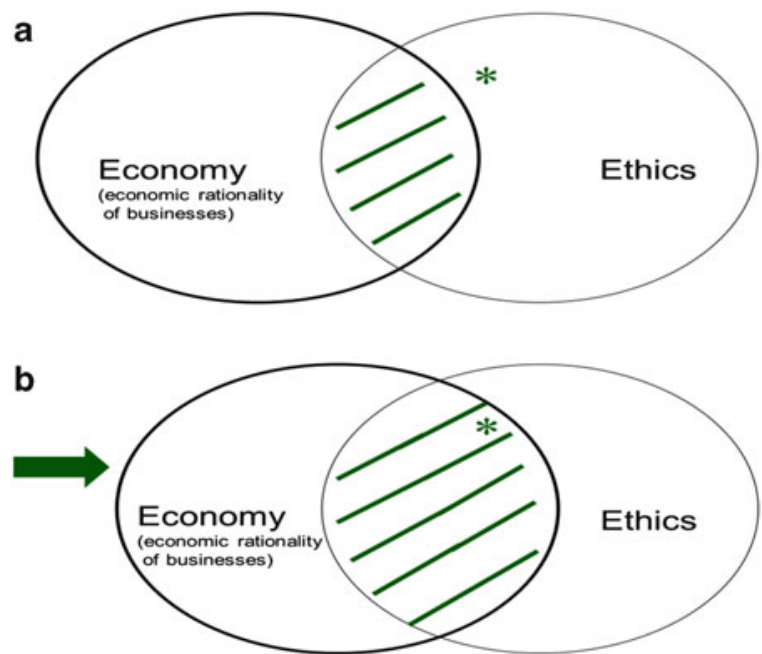

general theory of business ethics, but that both approaches highlight some of its 109 important dimensions. The two main theses are:

1. Individual leadership is important for ethics of organizations. However, ethical 111 leadership has to be embedded in suitable institutional frameworks. Institutions 112 matter!

2. Pure compliance approaches (closely related to risk management) show serious 114 shortcomings. They have to be supplemented (not substituted) by integrity 115 approaches.

\section{Theory of Business Ethics I: Traditional Economic Approaches}

From a neoclassical perspective on business ethics, it is argued that constraints for 118 businesses have been changed. In addition to the constraints set by the nation state, a 119 more and more professionalized and better organized civil society limits the actions 120 of businesses. Businesses at the end of the twentieth century and at the beginning 121 of the twenty-first century cannot undertake business activities "at all costs" but 122 increasingly have to legitimize their actions. Since the absence of legitimacy results 123 in increased costs and/or reduced profits, businesses try to deal with these new 124 requirements. This very simple idea is illustrated in the following figure (Fig. 1):

From a neoclassical perspective, businesses take ethical issues into account if -126 and only if - "they pay off". The (*) symbolizes an ethical issue, such as child 127 labor in developing countries, products or production processes that lead to negative 128 ecological consequences, and so forth. While in situation A these aspects are not 129 part of the rationality of the firm, in situation B they are included in the costing 130 


\section{Author's Proof}

Beyond Risk Management, Toward Ethics: Institutional und Evolutionary Perspectives

process and utility calculations since the economic constraints have changed. This 131 shift might have different reasons: a new law (such as an obligation to use new 132 industrial filters to avoid $\mathrm{CO}_{2}$ emissions), new market opportunities resulting from 133 a value shift in society (such as "ethical" (niche) products), or the need to "avoid 134 negative attention" (Nell-Breuning) by NGOs, the media, and finally consumers 135 (such as in the case of child labor). To sum up, we can distinguish three important 136 external, societal reasons for businesses to incorporate ethics into their economic 137 rationality (Paine 2003): changes in the political framework, risk management as a 138 form of "civil positioning", and market positioning. $\quad 139$

Apart from these external drivers of "sustainable change", businesses see ethical, 140 or better, moral issues as an important means for improving the performance 141 of their organizations. While neoclassical economics has assumed firms to be 142 black boxes, the New Institutional Economics investigates - among others - the 143 coordination mechanism of social actions within organizations. It is well known 144 that this field of research has led to a huge number of publications and the 145 emergence of three interrelated approaches within the New Institutional Economics 146 (see also the overview by Williamson 2000): property-rights-theory (Alchian and 147 Demsetz 1972), agency-theory (Fama 1980), and, last but not least, transaction cost 148 economics (Williamson 1975, 1985). 149

Whereas early concepts for an institutional foundation of a theory of the firm 150 particularly emphasized aspects of hierarchical control and economic incentives 151 (hard facts) to deal with the problem of social interaction within organizations, in 152 recent years soft facts, such as trust, integrity, credibility and fairness, have become 153 increasingly important in economic literature. We want to outline three important 154 reasons for this development:

1. Coordination: Social coordination through soft facts can reduce transaction costs 156 since expensive control and incentive mechanisms can become redundant. 157

2. Motivation: Transaction cost economics have been criticized as "bad practices" 158 (not only for ethical, but also for economic reasons) because control mechanisms 159 tend to become a self-fulfilling prophecy of one basic behavioral assumption of 160 transaction cost economics, which is opportunism. An increase in opportunism 161 (such as fraud), however, leads also to the necessity for better and more expensive 162 control systems (Ghoshal and Moran 1996; Moran and Ghoshal 1996). As a 163 consequence it is argued that the "atmosphere of transactions" and hence values 164 have to be taken into account. 165

3. Cooperation: While economic analyses usually stress the dimension of compe- 166 tition in a global economy, the German business ethicist Josef Wieland (1996, 167 1997, 1999, 2001) argues that there is another side of the coin. In conjunction 168 with increased trade and competition, one can also observe an increase in 169 cooperation among businesses owing to factors such as mergers and acquisitions 170 as well as business networks and more complex supply chains. The ability to 171 cooperate has become an important economic resource in times of globalization, 172 which can lead to positive economic consequences for businesses. 
It is important to note that this last argument of "governance ethics" (Wieland 174 1999, 2001) has a slightly different theoretical status in comparison with the rather 175 mainstream arguments of transaction cost economics. It is argued that values in 176 business organizations are sui generis (ontologically): Trust and fairness are not 177 the result of utility maximization; communicating such values has to be seen as 178 an original type of action and as an original type of interaction constituting social 179 relations. According to Max Weber's theory of action, this can be regarded as 180 value rationality (Wertrationalität), which is not a subtype of utility maximization 181 (Zweckrationalität) but an original type (Beschorner et al. 2012; Beschorner 2002). 182 In this respect, businesses are seen as multi-lingual actors. They not merely speak 183 and understand economic terms (profits) but also communicate in juridical, political 184 and moral terms as well as through other "language games". Communication in 185 terms of values is the basic and constitutive element of cooperation within the orga- 186 nization (intra-organizational) and between organizations (inter-organizational). 187 Intra- and/or inter-organizational cooperation may have an economic advantage 188 for businesses (Wieland 1999, 2001) since it helps stabilize social relations. This 189 argument by Wieland represents an important improvement in economic analyses. 190

In relation to business practices, implementing an institutional mechanism called 191 the compliance approach has been suggested. The main characteristic of this 192 approach is a system of explicit and unambiguous rules, such as codes of conducts, 193 to deal with certain moral issues. There are rules to prevent corruption, which 194 deal with the handling of gifts for example. And there are rules to prevent fraud, 195 irresponsible or abusive management, and mismanagement, as described above. $\quad 196$

\section{Theory of Business Ethics II: An Alternative Approach}

The suggested measures associated with compliance approaches are important and 198 relevant for certain issues in business ethics. However, I argue that these standard 199 procedures undermine ethical actions in the long run since a strict compliance 200 to defined rules lead to a lack of reflexivity within the organization. On the one 201 hand, this seems to be bad for business practices from an economic standpoint 202 since it tends to produce bureaucracy in the worst sense. On the other hand, a 203 compliance approach misinterprets the term "ethics" as "moral". Ethics includes 204 the requirement of (ethical) reflection about moral problems and not just compliance 205 with moral rules.

Unlike compliance concepts, integrity approaches (Beschorner 2005; Paine 207 1994; Steinmann and Olbricht 1998; Thielemann 2005) emphasize institutional 208 arrangements focused on a more dynamic and reflexive character of organizations. 209 Thus, integrity management should not be misunderstood as a pure form of individ- 210 ual ethics but as a more fruitful linkage between individual actions and institutional 211 arrangements that fosters ethical behavior. Such a change in perspective leads to 212 a different understanding of business ethics since intra- and inter-organisational 213 (institutional) arrangements differ from compliance approaches. They emphasize 214 


\section{Author's Proof}

Beyond Risk Management, Toward Ethics: Institutional und Evolutionary Perspectives

the need for an open organization (open dialogue with external as well as internal 215 stakeholders) rather than the closedness of the organizational processes (through 216 certain compliance rules) (Badura 2002; Ulrich 1997).

Moreover, I argue that there is a need for a more dynamic theory of the firm 218 in general and business ethics in particular, than is suggested by New Institu- 219 tional Economics. Here, we consider Evolutionary Economics as an interesting 220 candidate for providing us with new insights into firms. While New Institutional 221 Economics emphasizes the role of businesses as reactive adaptors within the market 222 system, an evolutionary perspective stresses the proactive function of businesses 223 as a guiding metaphor. Hence, Evolutionary Economics is also interested in the 224 transformation of market economies through businesses. As a matter of fact it is 225 crucial that a theory of firms deals with the most important 'cultural engine' in 226 modernity. Businesses have to be seen as more than just responders to somewhat 227 external signals (Beschorner 2007; Pfriem 2009). Businesses influence de facto the 228 institutional contexts through their (economic) actions and, thus, should be seen as 229 important actors that either limit new forms of societal and economic organization 230 or contribute to it in a positive manner. Current circumstances, especially ecological 231 problems and situations in developing countries, necessitate a systematic shift 232 toward a different society. To work out the relevance of businesses for sustainable 233 change - the limitations but also the opportunities - is the real challenge for 234 businesses ethics. Evolutionary Economics helps us achieve such an understanding. 235

An evolutionary theory of the firm leads us - at least from the point of 236 view of mainstream economists - to a radical change in perspective, where the 237 principle of utility maximization is questioned and replaced by routines as the basic 238 analytical unit. I will demonstrate that this perspective enables us to put the spotlight 239 on crucial but neglected issues in economic theory: the origin of capabilities 240 within corporations and innovations. Thus, businesses will be unchained from 241 an underlying incentive-response model in traditional economics, and economic 242 theories will be opened to recent discussions in economic sociology. The theoretical 243 perspective from Evolutionary Economics can contribute to a better understanding 244 of the above-mentioned integrity approach to business ethics.

The basic idea in Evolutionary Economics was developed by Nelson and Winter 246 (1982). They argue that traditional economic theories have little understanding 247 of innovations and economic change. While the existence of innovations in tra- 248 ditional economics comes out of a "book of blueprints", economic change is 249 mainly explained through somewhat external shocks. The term "evolutionary" in 250 Evolutionary Economics seems directly linked to Darwin's ideas in evolutionary 251 biology and lets us assume a naive transfer of biological metaphors and mechanisms 252 to economic theory. This, however, is not the case for most scholars in Evolutionary 253 Economics. "Evolution" is seen as a term that focuses on aspects of development 254 and change. Blind selection in Darwin's evolutionary biology is merely a subtype of 255 a general process of change and development (Hodgson 1993). Indeed, a Darwinian 256 approach is rejected by most evolutionary economists. In contrast, they argue that 257 their "theory is unabashedly Lamarckian"(Nelson and Winter 1982, 11) and so 258 Evolutionary Economics is based on an interpretative theory of action; hence, on 259 a more adequate conception for social sciences. 


\section{Author's Proof}

The basic category of this theory of action is routines or habits. As in transaction 261 cost economics, it is argued that actors act through bounded rationality. However, 262 unlike transaction cost economics, bounded rationality is not explained as a lack 263 of information (due to opportunism). Bounded rationality from an evolutionary 264 perspective is the result of the actor's cognitive limitation. Hence, Evolutionary Eco- 265 nomics emphasizes thick versus thin bounded rationality (Foss 2001; Lindenberg 266 1998). The terms routines or habits characterize cognitive schemata or cognitive 267 frames that are the basis for decision-making processes and thus - in comparison 268 to traditional economic approaches - "the explanatory arrow [runs] in the opposite 269 direction: instead of habits being explained in terms of rational choice, rationale 270 choice ... [is] explained in terms of habits" (Hodgson 1998, 178). In this regard, 271 five aspects of an evolutionary theory of the firm are relevant here. 272

First, a business is seen as a bundle of routines. Business performance strongly 273 depends on the ability of businesses to organize these routines in a fruitful way. 274 Hence, unlike markets, firms have the ability to accumulate knowledge and to inno- 275 vate. While markets are built on exchange, businesses are built on (the organization 276 of) knowledge.

Second, Coase's (1937) question about the existence of the firm can there- 278 fore be answered by Evolutionary Economics in a manner different from, albeit 279 complementary to, that of New Institutional Economics. Firms exist owing to the 280 fact that markets cannot produce innovations. Firms are neither regarded as a 281 somewhat strange anomaly within a fantastic coordination mechanism called the 282 market (Neoclassical), nor are they merely seen as a facilitator to reduce the cost of 283 social contracts (New Institutional Economics). As an alternative, the organization 284 of firms is described as an original modus of coordinating social actions with an 285 original outcome: capabilities, knowledge and innovations.

Third, since knowledge within firms is not completely available in explicit form 287 but mainly part of implicit routine-orientated actions, it cannot be bought on markets 288 or copied from competitors.

Fourth, institutional arrangements within organizations do not merely have to 290 take into account the effective coordination, motivation, and cooperation of social 291 actions (New Institutional Economics, see above) but have to simultaneously foster 292 circumstances under which certain capabilities can emerge. This perspective permits 293 us to develop a richer understanding of the relevance of certain organizational 294 capabilities. While transaction cost economics merely emphasizes the effects of one 295 certain resource for transactions, an evolutionary perspective also raises the question 296 of the origin of this important organizational resource. Moreover, the resource- 297 or competence-based approach in Evolutionary Economics regards cooperation 298 abilities as just one important organizational resource. Creative, learning, and 299 innovative capabilities are at least as important as cooperation.

The following figure summarizes the above arguments from Evolutionary Eco- 301 nomics, compares them with Transaction Cost Economics, and outlines the relation- 302 


\section{Author's Proof}

Beyond Risk Management, Toward Ethics: Institutional und Evolutionary Perspectives

Table 1 Transaction cost economics, evolutionary economics, and ethics

\begin{tabular}{|c|c|c|}
\hline & Transaction cost economics & Evolutionary economics \\
\hline $\begin{array}{l}\text { Theory of action (bounded } \\
\text { rationality) }\end{array}$ & $\begin{array}{l}\text { Weak bounded rationality } \\
\text { (lack of information) }\end{array}$ & $\begin{array}{l}\text { Strong bounded rationality (lack } \\
\text { of cognitive abilities) }\end{array}$ \\
\hline Existence of firms & Reduce transaction costs & Enables innovation \\
\hline Organizations as & Nexus of contracts & $\begin{array}{l}\text { Bundle of routines } \rightarrow \text { knowledge, } \\
\text { capabilities (explicit and } \\
\text { implicit) }\end{array}$ \\
\hline Institutional arrangements & Stabilizing social relations & Enabling change \\
\hline Relevance of soft facts & $\begin{array}{l}\text { Cooperation in and } \\
\text { between organizations }\end{array}$ & $\begin{array}{l}\text { Development of organizational } \\
\text { capabilities, especially } \\
\text { creative, learning, and } \\
\text { innovative capabilities }\end{array}$ \\
\hline Relation to ethical issues & $\begin{array}{l}\text { Avoidance of opportunism, } \\
\text { fraud, etc. (defensive) }\end{array}$ & $\begin{array}{l}\text { Enabling sustainable change } \\
\text { through business practices } \\
\text { (proactive) }\end{array}$ \\
\hline $\begin{array}{l}\text { Institutional arrangements } \\
\text { related to ethical issues }\end{array}$ & Compliance approach & Integrity approach \\
\hline
\end{tabular}

Table 2 Ethical measures in corporations (examples)

\begin{tabular}{llr}
\hline $\begin{array}{l}\text { Compliance approach to avoid } \ldots \\
\text { through ... }\end{array}$ & Risk management systems & $\mathrm{t} 2.1$ \\
& Codes of conducts & $\mathrm{t} 2.2$ \\
& Corrective organizational measures & $\mathrm{t} 2.3$ \\
& Avoidance of opportunism, fraud, etc. & $\mathrm{t} 2.4$ \\
& Specific anti-fraud training for management & $\mathrm{t} 2.5$ \\
Integrity approach to enable & Social standards to Bind on certain values (e.g. SA 8000) & $\mathrm{t} 2.6$ \\
sustainable change through & Fair dialogs with stakeholders & $\mathrm{t} 2.7$ \\
& Ethical corporate philosophy (mission and vision for a & $\mathrm{t} 2.8$ \\
& $\quad$ just society) & $\mathrm{t} 2.9$ \\
& Organizational measures to build ethical capabilities & $\mathrm{t} 2.10$ \\
& Ethical learning processes & $\mathrm{t} 2.11$ \\
& Development of personal integrity & $\mathrm{t} 2.12$ \\
& Social standards to foster reflexivity and dialogs & (e.g. AA 1000)
\end{tabular}

\section{Business Ethics: Toward a Socio-Economic Perspective}

What are the consequences of the general firm-theoretical perspective we have 305 outlined with respect to New Institutional Economics and Evolutionary Economics 306 for business practices? And how are the compliance and integrity approaches related 307 to each other? Table 2 outlines examples of ethical measures applied by corporations 308 from compliance and integrity perspectives: 309

I consider risk management and compliance approaches mainly as direct strate- 310 gies for preventing fraud (as noted above), economic crime, and irresponsible or 311 
abusive management and mismanagement. As such they are helpful in avoiding "bad 312 practices" in businesses. However, as stated earlier a strict compliance approach has 313 some serious shortcomings:

1. Compliance approaches tend to moral positivism since the orientation on certain 315 rules is underlined. This leads to a decrease in reflexivity about actions. 316

2. Compliance approaches are defensive in the sense that the main focus is on the 317 avoidance of "bad practices" rather than the development of "good practices". $\quad 318$

In contrast, integrity approaches emphasize ethical learning processes that should 319 lead to sustainable change in and through businesses. For example, (fair) dialogues 320 with external and internal stakeholders as facilitators to increase (ethical) reflexivity 321 are stressed. Businesses are seen as proactive actors, as cultural engines that do more 322 than merely react to external stimuli. Consequently, visions of "a just society" and 323 so forth are included in this perspective. In summary, the radical idea of integrity 324 approaches is the permanent reflection of businesses practices in the light of ethical 325 principles. As such, integrity within organizations is seen as a core competency for 326 businesses for economic reasons: If businesses extend their perception, they can 327 react and adapt more flexibly to economic and societal change.

I regard compliance and integrity approaches as complementary. Neither one 329 alone would contribute sufficient results. This is true for economic as well as ethical 330 "success". From an economic perspective, a compliance approach tends to build 331 bureaucracy in the worst sense (Weber's "iron cage"). The alternative, however, of a 332 high degree of reflexivity and permanent learning processes would also fail in a pure 333 form. Social relations and organizations need a certain degree of stability through 334 institutions. As the "management guru" Henry Mintzberg once correctly pointed 335 out, we cannot permanently learn: sometimes we have to work, too. 336

With respect to the ethical dimension, the arguments are similar: While com- 337 pliance approaches tend to moral positivism, integrity approaches overemphasize 338 ethical reflections. Eventually, the later would even undermine ethical behavior. 339 Whistle-blowing, as an example of a certain type of open communication with exter- 340 nal stakeholders, can obviously destabilize trust and credibility within organizations. 341 In summary, we understand compliance and integrity approaches as two ideal types 342 and quite contrary ideals that mark extreme positions in the field of business ethics. 343

However, given the dominance of compliance approaches in academic business 344 ethics as well as in business practices, I want to make it clear that these models 345 cannot serve as a general theory of business ethics since important issues are 346 neglected. Further research and concrete practical measures within firms should 347 investigate and work out a proactive role for businesses as drivers for sustainable 348 change rather than assuming them to be located in a given frame.

Biography Prof. Dr. Thomas Beschorner is Chair and Director of the Institute 350 for Business Ethics at St. Gallen University, Switzerland; 2001 Ph.D. at Max- 351 Weber-Kolleg für kultur- und sozialwissenschaftliche Studien, University of Erfurt 352 (Germany); Habilitation at the University of Oldenburg 2007; 2005-2006 Visiting 353 
Professor, McGill University, Montréal; 2007-2009 DAAD Professor, Université de 354 Montréal; since 2009: Professeur Associé at CCEAE, Université de Montréal, since 355 2011 at St. Gallen University.

\section{References}

Alchian, A.A., and H. Demsetz. 1972. Production, information costs, and economic organization. 358 American Economic Review 62(5): 777-795.

Badura, J. 2002. Ethische Beratung im Unternehmen - Konzepte im Vergleich. Zeitschrift für 360 Wirtschafts- und Unternehmensethik (zfwu) 3(3): 337-350.

Beschorner, T. 2002. Ökonomie als Handlungstheorie. Evolutorische Ökonomik, verstehende 362 Soziologie und Überlegungen zu einer neuen Unternehmensethik. Marburg: Metropolis. 363

Beschorner, T. 2004. Unternehmensethische Untersuchungen aus gesellschaftlicher Perspek- 364 tive. Von der gesellschaftsorientierten Unternehmenslehre zur unternehmensorientierten 365 Gesellschaftslehre. Zeitschrift für Wirtschafts- und Unternehmensethik (zfwu) 5(3): 255-276. 366

Beschorner, T. 2005. Integrität, Institution, Transformation. Korreferat zum Beitrag von Ulrich 367 Thielemann. Zeitschrift für Wirtschaft- und Unternehmensethik (zfwu) 6(1): 46-50. 368

Beschorner, T. 2007. Unternehmensethik. Theoretische Perspektiven für eine proaktive Rolle von 369 Unternehmen. In Gesellschaftliches Lernen und Nachhaltigkeit, ed. E. Hoffmann et al., 69-89. 370 Marburg: Metropolis-Verlag. $\quad 371$

Beschorner, T., and K. Vorbohle. 2007. Neue Spielregeln für eine (verantwortliche) 372 Unternehmensführung. In Corporate social responsibility und corporate citizenship, ed. 373 M. Schmidt and T. Beschorner, 117-124. München: Rainer Hampp Verlag. 374

Beschorner, T., T. Hajduk, and C. Schank. 2012. Ökonomie anders denken: Perspektiven Nach- 375 haltiger Entwicklung. In Politik nachhaltig gemacht. Wie man nachhaltige Politik gestaltet, 376 kommuniziert und durchsetzt, ed. Stiftung Bertelsmann, 73-99. Gütersloh: Bertelsmann-Verlag. 377

Coase, R. 1937. The nature of the firm. Economica 4(16): 386-405. 378

Fama, E.F. 1980. Agency problems and the theory of the firm. Journal of Political Economy 88(21): 379 288-307.

Foss, N.J. 2001. From "Thin" to "Thick" bounded rationality in the economics of organization: 381 An explorative discussion. Institut for Industriøkonomi og Virksomhedsstrategi, WP 2001-3, 382 Copenhagen. 383

Friedman, M. 1970. The social responsibility of business is to increase its profits. The New York 384 Times Magazine, 13 September 1970, 32-33,122-126. 385

Ghoshal, S., and P. Moran. 1996. Bad practice. A critique of the transaction cost theory. Academy 386 of Management Review 21(1): 13-47. 387

Hodgson, G. 1993. Economics and evolution. Bringing life back into economics. Cambridge: 388 Cambridge University Press. 389

Hodgson, G. 1998. The approach of institutional economics. Journal of Economic Literature 390 36(March): 166-192. 391

Homann, K. 1993. Wirtschaftsethik. Die Funktion der Moral in der modernen Wirtschaft. In 392 Wirtschaftsethik und Theorie der Gesellschaft, ed. J. Wieland, 32-53. Frankfurt a.M: Surkamp. 393

Homann, K., and F. Blome-Drees. 1992. Wirtschafts- und Unternehmensethik. Göttingen: Vanden- 394 hoeck. 395

Lindenberg, S. 1998. The cognitive turn in institutional analysis. Beyond NIE and NIS? Journal of 396 Institutional and Theoretical Economics (JITE) 154(4): 717-727. 397

Matten, D., and A. Crane. 2005. Corporate citizenship: Towards an extended theoretical conceptu- 398 alization. Academy of Management Review 30(1): 166-179. 399

Moran, P., and S. Ghoshal. 1996. Theories of economic organisation. The case for realism and 400 balance. Academy of Management Review 21(1): 58-72. 


\section{Author's Proof}

Nelson, R.R., and S.G. Winter. 1982. An evolutionary theory of economic change, 6th ed. 402 Cambridge/London: Belknap.

Paine, L.S. 1994. Managing for organizational integrity. Harvard Business Review 72(2): 106-117. 404

Paine, L.S. 2003. Value shift. Why companies must merge social and financial imperatives to 405 achieve superior performance. New York: McGraw-Hill.

Palazzo, G., and Andreas G. Scherer. 2006. Corporate legitimacy as deliberation: A communicative 407 framework. Journal of Business Ethics 66: 71-88.

Pfriem, R. 2009. Vom Sollen zum können Wollen. Auf dem Wege zu einer kultur- 409 alistischen Unternehmensethik und Unternehmenstheorie. In Betriebswirtschaftslehre und 410 Unternehmensethik, ed. Andreas Georg Scherer and M. Patzer, 65-84. Wiesbaden: Gabler- 411 Verlag.

Scherer, Andreas Georg, G. Palazzo, and D. Baumann. 2006. Global rules and private actors: 413 Toward a new role of the transnational corporation in global governance. Business Ethics 414 Quarterly 16(4): 505-532.

Steinmann, H., and T. Olbricht. 1998. Ethik-Management: Integrierte Steuerung ethischer und 416 ökonomischer Prozesse. In Umwelt und Wirtschaftsethik, ed. H. Steinmann and G.R. Wagner, 417 172-199. Stuttgart: Schäffer-Poeschel Verlag.

Thielemann, U. 2005. Compliance und Integrity - Zwei Seiten ethisch integrierter 419 Unternehmensführung. Lektionen aus dem Compliance-Management einer Großbank. 420 Zeitschrift für Wirtschafts- und Unternehmensethik (zfwu) 6(1): 31-45. 421

Ulrich, P. 1997. Integrative Wirtschaftsethik. Grundlagen einer lebensdienlichen Ökonomie. 422 Bern/Stuttgart/Wien: Haupt.

Wieland, J. 1996. Ökonomische Organisation, Allokation und Status. Tübingen: Mohr Siebeck. 424

Wieland, J. 1997. Die Neue Organisationsökonomik. Entwicklungen und Probleme der Theoriebil- 425 dung. In Theorien der Organisation. Die Rückkehr der Gesellschaft, ed. G. Ortmann, J. Sydow, 426 and K. Türk, 35-66. Opladen: Westdeutscher Verlag.

Wieland, J. 1999. Die Ethik der Governance. Marburg: Metropolis-Verlag.

Wieland, J. 2001. The ethics of governance. Business Ethics Quarterly 11(1): 73-87.

Williamson, O.E. 1975. Markets and hierarchies: Analysis and antitrust implications. A study in 430 the economic of internal organization. New York/London: The Free Press. 431

Williamson, O.E. 1985. The economic institutions of capitalism: Firms, markets, relational 432 contracting. New York: The Free Press.

Williamson, O.E. 2000. The new institutional economics: Taking stock, looking ahead. Journal of 434 Economic Literature 38: 595-613. 